\title{
THE INFLUENCE OF THE EFFECTIVENESS OF FARMER GROUP ON INNOVATION ADOPTION OF INTEGRATED CROP MANAGEMENT MODEL OF THE NATIONAL STRATEGIC FOOD CENTER IN KAPUAS REGENCY, CENTRAL KALIMANTAN PROVINCE OF INDONESIA
}

\author{
Prajawahyudo Tri \\ Doctoral Program of Agricultural Science, University of Brawijaya, Malang \& \\ Faculty of Agriculture, University of Palangka Raya, Central Kalimantan, Indonesia
}

Hidayat Kliwon, Yuliati Yayuk, Cahyono Edi Dwi

Faculty of Agriculture, University of Brawijaya, Malang, Indonesia

*E-mail: prajawahyudotri@yahoo.com

\begin{abstract}
Variable of the effectiveness of farmer groups (exogenous) is one of the variable that affect the level of innovation adoption (endogenous) of integrated crop management model of lowland rice. The effectiveness of farmer groups consists of 4 (four) indicators, namely performance, satisfaction, quality and commitment. The effect of the effectiveness of farmer group variables can result in a decrease in the level of adoption of technological innovations in farmer groups. The component of integrated crop management model innovation adoption consists of two technological components, namely basic technological components and selected technological components. This study aims to analyze the influence of farmer group effectiveness on the level of adoption of innovation with the integrated crop management model approach of national strategic food centers in Kapuas Regency, Central Kalimantan. The results of the descriptive statistical analysis of the average value of the effectiveness of farmer groups variable equal to 3.874 are included in the good category, while the average value of the innovation adoption level variable equal to 4.475 includes the category of very appropriate recommendations. Data processing using the PLS-SEM (Partial Least SquareStructural Equation Modelling) method. The fact of the study results prove that the effectiveness of farmer group variable has a significant effect on the level of innovation adoption of farmer groups, where the T-statistic value 7,643 > T-table 1,96 (Two tailed) and the path coefficient of 0,305 shows that there is a significant and positive influence, meaning that the higher the effectiveness of the farmer group will lead to the higher influence of the level of innovation adoption. The value of determination coefficient of 0.093 shows that the level of innovation adoption is influenced by the effectiveness of farmer groups of $9,30 \%$, the rest $90,70 \%$ is influenced by other factors which not contained in the model.
\end{abstract}

\section{KEY WORDS}

Effectiveness of farmer group, level of innovation adoption, integrated crop management.

Food production centers, especially rice in Indonesia, are uneven. Based on data on the national midterm plan for food and agriculture in 2015-2019, in 2012 rice production of around $53 \%$ was on Java island, Sumatra Island $23 \%$, Sulawesi island $11 \%$, Kalimantan island $7 \%$, Nusa Tenggara island $5 \%$, and only $1 \%$ in Maluku and Papua. In addition to the agricultural sector, Java island is also experiencing progress in other sectors every year. Centralization of various development sectors in Java island has caused many paddy fields to be converted into other sectors, such as housing, industry, roads and other sectors (Rusono, 2014). Van Tran (1998), Kaputra (2013), Xuan (2018), Dasgupta et al. (2018), Berg \& Tam (2018), Zarić et al. (2018), found that the cause of the decline in rice production was an increase in population, changing patterns of consumption of the population, narrowing of paddy fields due to land conversion, and the shrinking of land productivity levels. In order to maintain the continuity of production, the expansion of the rice planting area must be 
immediately diverted to outside Java where the land is still quite extensive. The government's efforts to maintain food self-sufficiency are by improving the quality of intensification, extensification, diversification and rehabilitation of agricultural land. Extensification program through opening new fields, especially in areas that already have irrigation networks outside Java. Although the cost of clearing of paddy fields is quite expensive, with the application of the right technology package and appropriate it is expected that rice production will increase.

The quality of human resources plays an important role in agricultural development activities (Rosenzweig, 1977; Kidd et al., 2000; Swanson, 2005; Xie and Zhong, 2006; Xuan, 2018; Zarić et al., 2018). Existing social reality indicates that the main actors of agricultural development in Indonesia are small farmers (planters, breeders, and fishermen). The perpetrators are still categorized as weak entrepreneurs, either in capital, education, skills, technology, and in their mental spirit to progress and develop. Thus, the main actors and business actors are expected to be able to build competitive and sustainable farming so that they can increase their bargaining position. Therefore, the capacity and capability of farmer groups must be continuously improved, one of them is through extension activities with a group approach (Ministry of Agriculture of the Republic of Indonesia, 2013).

Empowerment of national strategic food center farmer groups, namely rice, corn, soybeans, various chilies, shallots, sugar cane and beef, the effectiveness is still doubtful. Achievement of the target of seven national strategic commodities must be supported and maintained. Agricultural HR Development and Extension Agency responsible for preparing agricultural human resources either extension agents, officers and farmers to become reliable actors through an integrated farmer empowerment movement supported by counseling, education and training. The empowering activity of farmer groups of national strategic food center conducted in 24.000 (Agricultural Extension Work Areas) in 34 (Thirtyfour) provinces which sourced from the 2016 Extension Center Deconcentration Fund (Ministry of Agriculture, 2015). Kapuas Regency Central Kalimantan Province is one of the locations of national strategic food centers in improving the quality of human resources for the achievement of the target of seven national commodities. In order to achieve rice production targets, effectiveness is a key factor. The effectiveness of farmer groups is very important and is related to the level of adoption of innovation, because effectiveness involves the effort to achieve the stated goals. The effectiveness of farmer groups in the location of national strategic food centers in Kapuas Regency, Central Kalimantan Province can influence the level of adoption of integrated crop management models of lowland rice, so that it will have an impact on an increase in production.

\section{RESEARCH FRAMEWORK}

The group behavior model to achieve group effectiveness is influenced by elements of input, process, and environment. Input at the group level consists of group composition and group structure. Group composition consists of skills, position, and heterogeneity, while in group structure consists of clarity of roles, clarity of goals, norms, tasks, measures, and leadership. Processes at the group level consist of openness of communication, support, conflict, strategy, role behavior, leadership, and decision making (Umstot, 1988). The Umstot group behavior model to achieve group effectiveness is influenced by elements of input, process, environment, and output. In the group behavior model, it appears that group effectiveness can be measured from 4 (four) indicators namely performance, quality, satisfaction, and commitment. Group effectiveness is influenced by various factors, both group internal factors and external or group environment (Umstot, 1988). (figure 2). Whereas according to Yunasaf (2007) group effectiveness is the success rate of the group to achieve its objectives. Some indicators of the effectiveness of the group include, among others, consist of; group productivity, group morals, and satisfaction levels of the members.

In the case of weighting there is no distinction between indicators of the forming of group effectiveness, because the indicators of the forming of the effectiveness is an inseparable unit. This means that each indicator is integrated and contributes equally to the forming elements of group effectiveness. Some of the results of previous studies indicate that 
the effectiveness of farmer groups influences the adoption of innovation. This means that if the farmer group is not effective it will result in a less optimal innovation adoption level so that it will have an impact on the increase in production and farming productivity. Research on the estimation of the effect of farmer group effectiveness with indicators of performance, satisfaction, quality and commitment to the level of innovation adoption of integrated crop management which consisting of basic technology components and selected technology components in Kapuas Regency is very important to be conducted, this is to examine how much influence of the farmer group effectiveness on the level of innovation adoption.

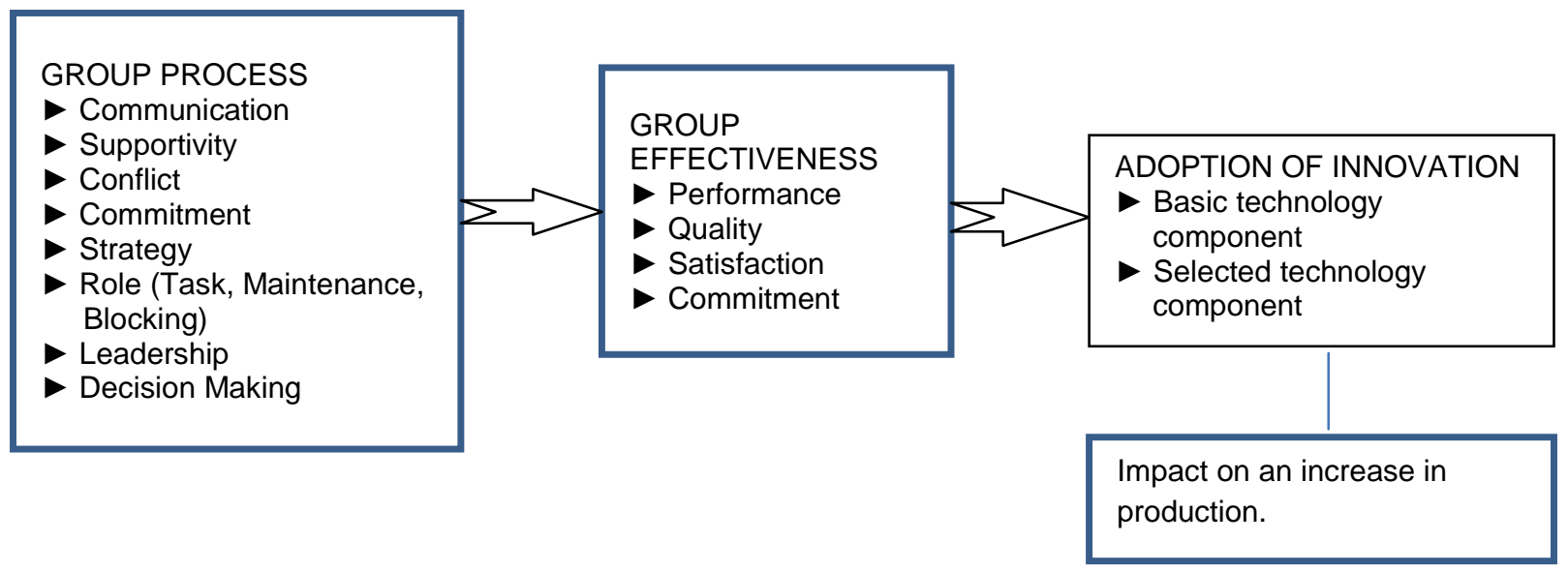

Figure 1 - Frame of Research Conceptual

The hypothesis of this study:

HO. The effectiveness of farmer groups does not have a significant effect on the level of innovation adoption of integrated crop management models of national strategic food centers.

\section{METHODS OF RESEARCH}

This research was conducted in Kapuas Regency Central Kalimantan Province. Geographically, Kapuas Regency is located between 08'48" until $3^{\circ} 27^{\prime} 00^{\prime \prime}$ South Latitude and $113^{\circ} 2^{\prime} 36^{\prime \prime}$ until $114^{\circ} 44^{\prime} 00^{\prime \prime}$ located on the equator. The climate in Kapuas Regency includes tropical and humid climates with minimal temperatures ranging from $21-23^{\circ} \mathrm{C}$ and maximum $36^{\circ} \mathrm{C}$. The intensity of solar radiation is always high and water resources are quite high.
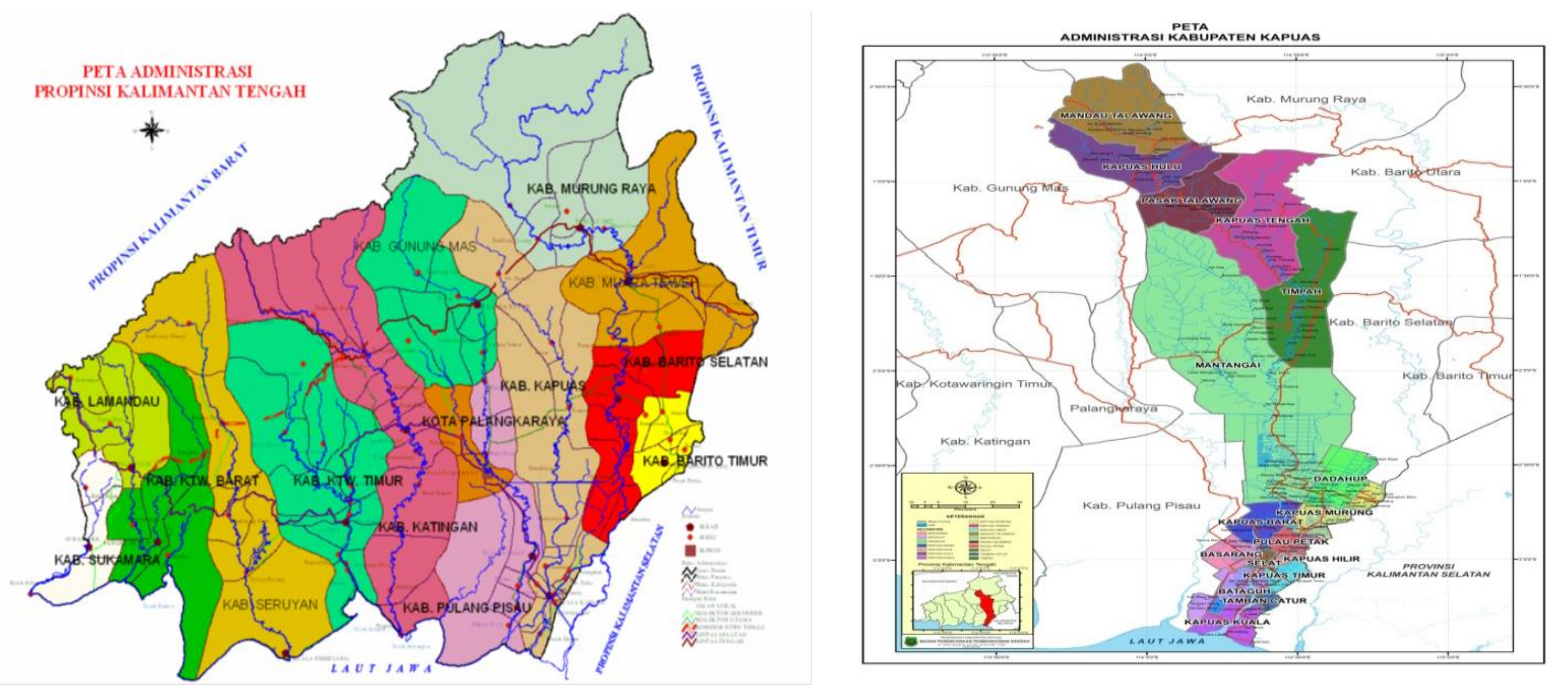

Figure 2 - Map of Location and Research Activities 
The most rainfall falls in December, ranging from 886-1.789 mm per year, while the dry month (dry season) occurs in April-August (Kapuas Regency BPS, 2017). The research location is one of the national strategic food centers which carried out in 34 provinces throughout Indonesia. Besides that, Kapuas Regency is a food center and has the largest contribution (41.59\%) compared to other regencies in Central Kalimantan Province.

The measurement of farmer group effectiveness and innovation adoption level uses a Likert scale, and the unit of analysis is farmer groups. The method of the sample determination is proportionate stratified random sampling, where farmer groups in the research area are recorded and made a list, then grouped into group strata according to the criteria of Department of Agriculture of the Republic of Indonesia. Next, each strata is taken as a group sample (respondents) randomly with the distribution of the number of groups representing the strata of the beginner class and advanced classes namely equal to $11 \%$ respectively. According to Arikunto (2006) if the number of subjects (samples) is large > 100, it can be taken between $10-15 \%$ or $20-25 \%$ or more. While for the Partial Least Square (PLS) analysis, the sample size is at least 30 (Ghozali, 2014). Then 5 (five) members (farmers) randomly selected from each selected farmer group, namely 2 administrators and 3 non-management members, so that the number of respondents from the two classes of ability of the selected farmer groups totaled 155 farmer respondents (Table 1).

Table 1 - Number of Respondents Based on Farmer Group Ability Classes

\begin{tabular}{cccccc}
\hline No & $\begin{array}{c}\text { Farmer Group Ability } \\
\text { Class }\end{array}$ & $\begin{array}{c}\text { Number of Farmer } \\
\text { Groups }\end{array}$ & $\begin{array}{c}\text { Number } \\
\text { specified }\end{array}$ & $\begin{array}{c}\text { Number of group } \\
\text { sample }\end{array}$ & $\begin{array}{c}\text { Number of } \\
\text { respondents }\end{array}$ \\
\hline 1 & Beginner Class & 234 & $11 \%$ & 26 & 130 \\
2 & Advanced Class & 42 & $11 \%$ & 5 & 25 \\
& Total & 276 & & 31 & 155 \\
\hline
\end{tabular}

Source: The Agriculture Service of the Kapuas Regency processed (2018).

Table 2 - The names of farmer groups as unit of analysis

\begin{tabular}{|c|c|c|c|c|}
\hline No & Name & Year Established & Class & Total members \\
\hline 1 & Maju Bersama KP & 2015 & Advanced & 25 \\
\hline 2 & Berkat Sepakat & 2012 & Advanced & 25 \\
\hline 3 & Karya Bersama II & 2012 & Advanced & 25 \\
\hline 4 & Hatantiring & 1980 & Advanced & 37 \\
\hline 5 & Berkat Bersama & 1981 & Advanced & 31 \\
\hline 6 & Berkat Makmur & 1977 & Beginner & 63 \\
\hline 7 & Sehaluan & 1987 & Beginner & 49 \\
\hline 8 & Taruna Mukti & 2011 & Beginner & 21 \\
\hline 9 & Sumber Hasil & 2002 & Beginner & 40 \\
\hline 10 & Terusan Sakti & 1992 & Beginner & 30 \\
\hline 11 & Karya Hanua aya & 1994 & Beginner & 30 \\
\hline 12 & Sri Rejeki & 1992 & Beginner & 25 \\
\hline 13 & Karya Sadar & 1990 & Beginner & 40 \\
\hline 14 & Subur Makmur & 1989 & Beginner & 30 \\
\hline 15 & Berkat Keluarga & 2004 & Beginner & 25 \\
\hline 16 & Bina Bersama & 2002 & Beginner & 72 \\
\hline 17 & Eka Karya & 1990 & Beginner & 27 \\
\hline 18 & Hijau Berseri & 2005 & Beginner & 28 \\
\hline 19 & Putra Dewata & 1984 & Beginner & 25 \\
\hline 20 & Dharma Karya & 1983 & Beginner & 30 \\
\hline 21 & Budi Karya & 1985 & Beginner & 35 \\
\hline 22 & Tunas Mekar & 1986 & Beginner & 40 \\
\hline 23 & Budi Jaya & 1984 & Beginner & 37 \\
\hline 24 & Tani Mukti & 1987 & Beginner & 30 \\
\hline 25 & Karya Sadar & 1987 & Beginner & 52 \\
\hline 26 & Sido Dadi & 1985 & Beginner & 40 \\
\hline 27 & Margo Rejo & 1985 & Beginner & 34 \\
\hline 28 & Suka Maju & 1987 & Beginner & 20 \\
\hline 29 & Margo Mulya & 1990 & Beginner & 34 \\
\hline 30 & Borneo Makmur & 2015 & Beginner & 27 \\
\hline \multirow[t]{2}{*}{31} & Berkat Cangkal & 2017 & Beginner & 15 \\
\hline & Average & & & 29,65 \\
\hline
\end{tabular}

Source: Research data processed, 2018. 
Based on table 2, it can be seen that the year of establishment or formation of farmer groups ranges from 1977 - 2017, so the age of the most recent farmer groups is 1 (one) year and the longest is 41 (forty one) years. The number of members of farmer groups in each group ranged from 15 - 72 people, while the average number of members of farmer groups was 29,65 . If referring to the guiding regulations, the ideal number of members of the farmer group is between 20-25 people or according to local circumstances. The farmer group as a unit of analysis consists of 2 (Two) ability strata namely advanced class and beginner class.

Data collected in this study are primary data and secondary data. Primary data is data obtained from respondents through interviews using questionnaires arranged on a Likert scale. Data collection uses a technique triangulation method of the problem to be collected. Triangulation method is a technique of collecting data through interviews, observation, questionnaires, and documentation (Sugiyono, 2015).

Processing and analysis of Data. The construct validity shows how well the results obtained from the use of a measurement are in accordance with the theory (concept) used to define a construct. A strong correlation between constructs and statement items and a weak relationship with other variables is one way to test the construct validity. The construct validity test can be measured by loading score parameters. Rule of Thumb $>0.70$ and use the AVE parameter, Communality. AVE score must be $>0,50$, and Communality $>0,50$. Reliability test to measure the consistency of measuring instruments in answering statement items in research instruments (Cooper et al., 2006, and Hair et al. 2017). Test reliability is measured by the value of Cronbach's Alpha and Composite Reliability. Rule of Thumb the value of Alpha or Composite Reliability must be $>0,70$, even though the value of 0,60 is still acceptable. But CR is better used in PLS techniques to estimate the internal consistency of a construct (wiyono, 2011; Abdillah and Jogiyanto, 2015) (Table 3).

Table 3 - Measurement Model Test (Outer Model) and PLS Assessment Criteria

\begin{tabular}{lll}
\hline Model Test & Output & Criteria \\
\hline $\begin{array}{l}\text { Outer Model } \\
\text { (Indicator }\end{array}$ & a.Convergent Validity & a.The value of loading factor 0,50-0,60 (already considered sufficient) \\
Test) & C. Averiminant Validity & $\begin{array}{l}\text { b.The value of cross loading correlation with its latent variables must } \\
\text { be greater than the correlation with other latent variables }\end{array}$ \\
& $\begin{array}{l}\text { Variance Extracted (AVE) } \\
\text { d.Composite Reliability }\end{array}$ & $\begin{array}{l}\text { c. The AVE value must be }>0,50 \\
\text { d. The value of Cronbach's alpha or Composite Reliability that is good } \\
\text { must be }>0,70, \text { even though the value of } 0,60 \text { is still acceptable }\end{array}$ \\
\hline
\end{tabular}

Source: Hair et al. (2017).

The principle of structural model examines the effect of one latent variable with other latent variables both exogenous and endogenous (Testing the hypotheses). Testing is done by looking at the percentage of variance described, namely $\mathrm{R}^{2}$ (coefficient of determination) for endogenous latent variables modeled. The value of $R^{2}$ measures the level of variation in changes of exogenous variables towards endogenous variables. the higher the $\mathrm{R}^{2}$ value means the better the prediction model of the proposed research model. Stability (measurement consistency) of estimation is tested using a statistical t-test obtained through a bootstraping procedure (Wiyono, 2011) (Table 4).

Table 4 - Structural Model Test (Inner Mode/) and PLS Assessment Criteria

\begin{tabular}{lll}
\hline Model Test & Output & Criteria \\
\hline Inner Model & a.The coefficient of & a.The coefficient of determination $\left(R^{2}\right)$ value is between $0-1$ \\
(Hypothesis & determination $\left(R^{2}\right)$ for & $(0 \%-100 \%)$ the higher the value of $R^{2}$, the higher the \\
Testing) & $\begin{array}{l}\text { endogenous latent variables } \\
\text { b.Parameter coefficient, and } \\
\text { t-statistics }\end{array}$ & $\begin{array}{l}\text { contribution to endogenous latent variables due to exogenous } \\
\text { latent variables. } \\
\text { b. Estimated values for path relationships in the structural model } \\
\text { must be significant, which can be obtained by bootstraping } \\
\text { procedures }\end{array}$ \\
\hline
\end{tabular}

Source: Hair et al. (2017). 


\section{RESULTS AND DISCUSSION}

The effectiveness of the farmer group is the success of the business carried out by the farmer groups in the process of achieving the stated objective. Indicators of effectiveness of farmer groups are measured based on the Umstot model (1988), namely ; 1) performance; 2) quality; 3) satisfaction; and 4) commitment (Table 5).

Table 5 - Measurement of Farmer Group Effectiveness

\begin{tabular}{lll}
\hline Variable & Indicator & $\begin{array}{l}\text { Measurement } \\
\text { Category }\end{array}$ \\
\hline Effectiveness of & Performance measured based on aspects of ability: a) planning & 5. very good \\
farmer groups & activities; b) carry out and obey the agreement; c) use tools and & 4.good \\
& agricultural machinery; d) marketing the production, and e) developing & 3. fairly good \\
& the production. & 2. less good \\
& Quality is measured based on the ability of farmer groups to provide & 1. very not good \\
& more value for group members. & \\
& Satisfaction is measured based on the production produced, provision of \\
& production facilities, eradication of plant pests and diseases, credit & \\
& facilities, openness and availability of information and income earned. & \\
& Commitment is measured based on the potential which owned by the \\
& group to progress and develop (sustainability) & \\
\end{tabular}

The effectiveness of farmer groups is very important for the sustainability of farmers' groups (Nyang'au et al., 2018; Bachev, 2019; Wuepper et al., 2018; Knickel et al., 2018; Gabel et al., 2018; Wijaya et al., 2018; Hidayat et al.,2018; Giomi, et al., 2018; Bloomfield et al., 2018), because by their effectiveness existence, the farmer groups objectives can be achieved. The effectiveness of farmer groups makes farmer groups able to analyze group goals that have not been achieved so that the planning of group activities will run in a more productive and effective direction. The urgency of the effectiveness of an organization, as proposed by Drucker in Hersey and Blanchard, (2004) states that effectiveness is the basis for organizational success, including at the group level (Hopkin, 2018; Kirschenbaum, 2019; Sherman et al., 2018). The level of innovation adoption is the level of application of technological components of the Integrated Crop (Jerop et al., 2018; Jamil et al., 2018; Silva et al., 2018; Stevenson et al., 2019; Peshin et al., 2019). Management model of lowland rice farming through Movement of Integrated Crop Management Application on farmer response indicators from those not recommended until as recommended for: a) basic technology components; and b) selected technology components (Ministry of Agriculture of the Republic of Indonesia, 2016) (Table 6).

Table 6 - Measurement of the Level of Innovation Adoption of Farmer Group

\begin{tabular}{lll}
\hline Variable & Indicator & Measurement Category \\
\hline Level of Innovation Adoption & Measured based on the level of adoption of the & 5. very recommended \\
of Integrated Crop & recommended technology components consisting & 4. as recommended \\
Management & of: & 3. fairly recommended \\
& a.Basic technology components: Use of superior & 2.less recommended \\
& varieties, quality and healthy seeds, administration & 1. very not recommended \\
of organic materials, fertilization, integrated pest & \\
control & \\
& b. Selected technology component: tillage, crop \\
& management, irrigation, weeding with porcupines \\
& (gasrok), handling of harvest and post-harvest. & \\
\hline
\end{tabular}

Based on a survey on 155 respondents taken from 2 (Two) Sub-districts in Kapuas Regency, Central Kalimantan Province, namely Selat Sub-districts and Bataguh Subdistricts. In general, the characteristics of the respondent farmers namely regarding with age, education level, cultivated land area, side jobs, tribe or ethnicity, and farming experience (Table 7).

The age characteristics of farmer group members vary between 20 - 69 years. Distribution of categories of respondents with the age range between 35 - 49 years was the 
most dominant at 74 people (47,75\%), Cumulatively $144(92,90 \%)$ respondents were in the productive age category. This fact is supported by Burhansyah (2014) which states that productive age is capital in conducting farming activities. The average respondent is 46,98 years old. The distribution characteristics of the respondents were most dominant at the junior high school level (SLTP) namely equal to $47,74 \%$. Then followed by respondents with elementary school education (SD) of $25,81 \%$, high school (SMU) educated of $22,58 \%$, and about 3,87\% have an education of Diploma or College. Hapsari (2012) states that education can make people think logically, systematically, and wisely. With higher formal education will be better able to analyze the benefits that will be obtained from the activities to be carried out. The characteristics of cultivated land area of farmers or the most respondents are in the area of medium cultivated land, namely the range between $1-3$ ha which is equal to $87,74 \%$. Then followed by farmers who have a large area of cultivated land which is above $3(>3)$ equal to $9,03 \%$ and respondents with the ownership of narrow-scale cultivated land area that is less than 1 ha $(<1)$ equal to $3,23 \%$. While the productivity of agricultural lowland rice area is an average of 4,43 tons/ha. Wahed (2015) stated that land area is one of the main factors in increasing production which affects the welfare of farmers, which in turn can also improve the welfare of farmers. The most dominant side job of members of farmer groups is as merchant/stall business at $35,60 \%$. Next working as a builder or construction worker is $27,12 \%$, farm laborers/hodge by $22,03 \%$, tailor amounted to $6,78 \%$, fishermen or fish keepers at $6,78 \%$, and chicken breeders at $1,69 \%$. The characteristics of respondents distribution based on the most dominant tribe or ethnic are the Javanese, $45,81 \%$. Then followed by the Banjar tribe $33,54 \%$, Balinese tribe amounted to $11,61 \%$, Dayak tribe equal to $8,39 \%$, and the least is the Batak tribe, only around $0,65 \%$. While the longest experience of farming is between $21-30$ years $(46,64 \%)$. This is supported by Putri's findings (2016) stating that the experience gained by someone can add to the knowledge and skills that are appropriate to the field of work involved.

Table 7 - Characteristics of Respondents

\begin{tabular}{|c|c|c|c|}
\hline Description & Category & Respondents & Percentage (\%) \\
\hline Age & $\begin{array}{l}20-34 \\
35-49 \\
50-64 \\
\geq 65\end{array}$ & $\begin{array}{l}18 \\
74 \\
57 \\
6\end{array}$ & $\begin{array}{l}11,61 \\
47,75 \\
36,77 \\
3,87\end{array}$ \\
\hline Total & & 155 & 100 \\
\hline Level of education & $\begin{array}{l}\text { Elementary School }(0-6) \\
\text { Junior high school }(7-9) \\
\text { High School }(10-12) \\
\text { Diploma / College }(13-17)\end{array}$ & $\begin{array}{l}40 \\
74 \\
35 \\
6\end{array}$ & $\begin{array}{l}25,81 \\
47,74 \\
22,58 \\
3,87\end{array}$ \\
\hline Total & & 155 & 100 \\
\hline Cultivated Land Area & $\begin{array}{l}\text { Narrow }(<1) \\
\text { Moderate }(1-3) \\
\text { Large }(>3)\end{array}$ & $\begin{array}{l}5 \\
136 \\
14 \\
\end{array}$ & $\begin{array}{l}3,23 \\
87,74 \\
9,03 \\
\end{array}$ \\
\hline Total & & 155 & 100 \\
\hline Side job & $\begin{array}{l}\text { Hodge } \\
\text { Merchant (stall business) } \\
\text { Tailor } \\
\text { Chicken farmer } \\
\text { Builders (Building workers) } \\
\text { Fisherman (raising fish) } \\
\end{array}$ & $\begin{array}{l}13 \\
21 \\
4 \\
1 \\
16 \\
4 \\
\end{array}$ & $\begin{array}{l}22,03 \\
35,60 \\
6,78 \\
1,69 \\
27,12 \\
6,78 \\
\end{array}$ \\
\hline Total & & 59 & 100 \\
\hline Tribe or Ethnicity & $\begin{array}{l}\text { Jawa } \\
\text { Dayak } \\
\text { Banjar } \\
\text { Bali } \\
\text { Batak }\end{array}$ & $\begin{array}{l}71 \\
13 \\
52 \\
18 \\
1 \\
\end{array}$ & $\begin{array}{l}45,81 \\
8,39 \\
33,54 \\
11,61 \\
0,65 \\
\end{array}$ \\
\hline Total & & 155 & 100 \\
\hline Farming experience (years) & $\begin{array}{l}<10 \\
10-20 \\
21-30 \\
>30\end{array}$ & $\begin{array}{l}22 \\
53 \\
72 \\
8\end{array}$ & $\begin{array}{l}14,19 \\
34,19 \\
46,46 \\
5,16\end{array}$ \\
\hline Total & & 155 & 100 \\
\hline
\end{tabular}

Source: Research data processed (2018). 
The analysis results of statistical description of the effectiveness of farmer group variables (Y1) obtained the majority of respondents' answers are good answers with an average item between 3,477 to 4,174 (Table 8). This shows that the respondent gave a positive response to the variable item of the effectiveness of the farmer group (Y1). As for the effectiveness of farmer groups are as follows: a. average performance indicator 4.014, b. average quality indicator 3.790 , c. the average satisfaction indicator is 3.866 , and $\mathrm{d}$. average commitment indicator 3.825. Meanwhile the variable average value is 3.874 , included in the good category. The facts prove that the effectiveness of lowland rice farmer groups on performance indicators is the highest. From the analysis results of the variable description of the effectiveness of farmer group that need to be considered by farmer groups are several indicators including quality, satisfaction, and commitment. On quality indicators, namely on the item "crop quality as a result of farmer group activities" and "quality of agricultural production facilities which available in farmer groups" still have a low average value when compared to other items on the same indicator. On the satisfaction indicator, the item "ease for capital credit" still has a low average value, when compared to other items on the same indicator. Furthermore, on the commitment indicator, namely on the item "frequency of cooperation activities of farmer groups with cooperatives", and "frequency of farmer group cooperation activities with banks" still have a low average value, when compared to other items on the same indicator. But if we look at the overall results the average value of the effectiveness variable of the farmer group is in the range of hesitation and close to the agreement with the indicators of performance, quality, satisfaction and commitment, therefore it can still be increased to achieve an average value of strongly/ very agree. (Appendix 1).

The results of the description of the level of innovation adoption (Y2) obtained by the majority of respondents' answers is that the answers are sufficiently appropriate to be very appropriate with the average item between 2,852 to 4,813 . This shows that the respondent gave a very positive response to the item variable of the level of innovation adoption (Y2). As for the level of innovation adoption are as follows: a. basic technology component indicators the average is 4.350, and b. selected technology component indicators on average of 4.599. While the average value of the innovation adoption level variable is 4.475 , including in the very recommended category (Appendix 2). The level of innovation adoption of integrated plant management program/program through the Integrated Crop-Management Implementation Movement is the level of application of technological components in rice farming by farmers or farmer groups which consists of 2 (Two) components namely: 1) basic technology components, and 2) selected technology components. Basic technology components are components that must be applied (highly recommended) in the implementation of integrated crop management model of lowland rice, while the selected technology components are several components that can be selected based on location needs (conditions, willingness, and capabilities of local farmers) (Ministry of Agriculture, 2016). The results of this analysis indicate that it is necessary to pay attention to the basic technological component indicators, namely on items a.4"Fertilizing based on plant needs and soil nutrient status and the use of the BWD (Based on Leaf Color) method to measure $\mathrm{N}$ (Nitrogen) content and Rice Field Test Equipment to measure $\mathrm{P}$ (Phosphorus) \& $\mathrm{K}$ (Potassium) content received a very low response $(2,852)$ from respondents' assessment or farmer group members. This is because farmers feel that the available technology is still very limited and the price is too expensive. Besides that, in the selected technology component indicator, a small number of farmers still have not implemented the jajar legowo system and weeding is still done manually, by hand and machete.

Measurement Model Test (Outer Model). The result of measurement model test (outer model) on the effectiveness of farmer groups (Y1) and the level of innovation adoption (Y2) by the measurement of the reflective model obtained all indicators (observed variable) fulfill the feasibility test with the value of loading factor (Original Sample) $>0,50$ so that the indicator can be used. Discriminant validity is measured using cross loading with the criteria if the value of the loading factor in a corresponding variable is greater than the value of the 
indicator correlation in other variables then the indicator is declared valid in measuring the corresponding variable. Cross loading calculation results (Table 8).

Table 8 - Results of Outer Model discriminant validity with Cross Loading

\begin{tabular}{lll}
\hline Indicator & Y1 & Y2 \\
\hline Y1.1 & $\mathbf{0 . 7 9 4}$ & 0.314 \\
Y1.2 & $\mathbf{0 . 8 3 0}$ & 0.225 \\
Y1.3 & $\mathbf{0 . 8 0 4}$ & 0.204 \\
Y1.4 & $\mathbf{0 . 5 9 9}$ & 0.097 \\
Y2.1 & 0.258 & $\mathbf{0 . 8 4 3}$ \\
Y2.2 & 0.253 & $\mathbf{0 . 8 3 5}$ \\
\hline
\end{tabular}

Source: Research data processed (2018).

The result of measurement model test (outer model) on the variable of effectiveness of farmer groups (Y1) and the level of innovation adoption (Y2), with a reflective measurement model obtained all indicators meet the feasibility test with the value of loading factor (Original Sample) $>0,50$ so that the indicator can be used (Table 9).

Table 9 - Calculation Results of Measurement Model Coefficient (Outer Model)

\begin{tabular}{|c|c|c|c|c|c|c|}
\hline $\begin{array}{l}\text { Indicator } \\
\text { Variable }\end{array}$ & $\begin{array}{c}\text { Original } \\
\text { Sample }(\mathrm{O})\end{array}$ & $\begin{array}{l}\text { Sample } \\
\text { Mean (M) }\end{array}$ & $\begin{array}{l}\text { Standard } \\
\text { Deviation } \\
\text { (STDEV) }\end{array}$ & $\begin{array}{l}\text { Standard Error } \\
\text { (STERR) }\end{array}$ & $\begin{array}{l}\text { T Statistics } \\
\text { (|O/STERR|) }\end{array}$ & $\begin{array}{c}\mathrm{P}- \\
\text { value }\end{array}$ \\
\hline \multicolumn{7}{|c|}{ Effectiveness of Farmers Group } \\
\hline$Y 1.1<-Y 1$ & 0.794 & 0.791 & 0.041 & 0.041 & 19.140 & 0.000 \\
\hline$Y 1.2<-Y 1$ & 0.830 & 0.824 & 0.029 & 0.029 & 28.214 & 0.000 \\
\hline$Y 1.3<-Y 1$ & 0.804 & 0.797 & 0.044 & 0.044 & 18.311 & 0.000 \\
\hline$Y 1.4<-Y 1$ & 0.599 & 0.596 & 0.076 & 0.076 & 7.881 & 0.000 \\
\hline \multicolumn{7}{|c|}{ Level of Adoption of Innovation } \\
\hline$Y 1.1<-Y 2$ & 0.843 & 0.842 & 0.039 & 0.039 & 21.613 & 0.000 \\
\hline$Y 1.2<-Y 2$ & 0.835 & 0.829 & 0.050 & 0.050 & 16.830 & 0.000 \\
\hline
\end{tabular}

Source: Research data processed (2018).

Calculations to test the reliability of latent variables (constructs) are discriminant reliability(AVE), Cronbach'sAlpha (CA) and Composite Reliability (CR). The test criteria states if the AVE has the value $>0.50$, CA has the value $>0.60$ and CR must has the value $>$ 0.70 then the construct is declared reliable. The results of the AVE, CA and CR calculations indicate that variable reliability meets the requirements and can be used (Table 10).

Table 10 - The Results of Latent Variable Reliability (Construct)

\begin{tabular}{ccccccc}
\hline & AVE & Composite Reliability & Cronbachs Alpha & Communality & $R$ Square & Redundancy \\
\hline Y1 & 0.581 & 0.845 & 0.773 & 0.581 & & \\
Y2 & 0.704 & 0.827 & 0.580 & 0.704 & 0.093 & 0.065 \\
\hline
\end{tabular}

Source: Research data processed (2018).

Hypothesis Testing: Influence of the effectiveness of farmer groups $(X)$ on the level of innovation adoption $(Y)$.

Table 11 - Hypothesis test results

\begin{tabular}{cccccc}
\hline & Original Sample (O) & Standard Error (STERR) & T Statistics (|O/STERR/) & $P$-value & Description \\
\hline $\mathrm{Y} 1->\mathrm{Y} 2$ & 0.305 & 0.040 & 7.643 & 0.000 & Significant \\
\hline
\end{tabular}

Source: Primary research data processed (2018).

Table 12 - Structural model equation (Inner Model)

\begin{tabular}{ccc}
\hline & Original Sample $(\mathrm{O})$ & Equation \\
\hline $\mathrm{Y} 1->\mathrm{Y} 2$ & 0.305 & $\mathrm{Y}_{2}=0.305 \mathrm{Y}_{1}+\mathrm{e}$ \\
\hline
\end{tabular}

Source: Research data processed (2018). 
The result of Hypothesis test and structural model equations that the test of the influence of farmer group effectiveness variables ( $\mathrm{Y} 1)$ on the level of innovation adoption (Y2) obtained the value of T-statistic 7,643> T-table 1,960 (Two tailed) (Table 11) means that there is a significant influence of the effectiveness of the farmer group variables (Y1) on the level of innovation adoption (Y2) with a significance level of $5 \%$ (hypothesis accepted). In equation $\mathrm{Y} 2=0.305 \mathrm{Y} 1+$ path coefficient value $(0,305)$ (Table2) indicates a positive influence meaning that the higher the effectiveness of farmer groups (Y1) will lead to higher influence on the level of adoption of innovations (Y2). The equation also shows that the effectiveness of farmer groups $(\mathrm{Y} 1)$ with the level of adoption of innovation directly or linearly proportional (Y2). Adoption of lowland rice technological innovation is known based on the results of the application of technology by farmers.

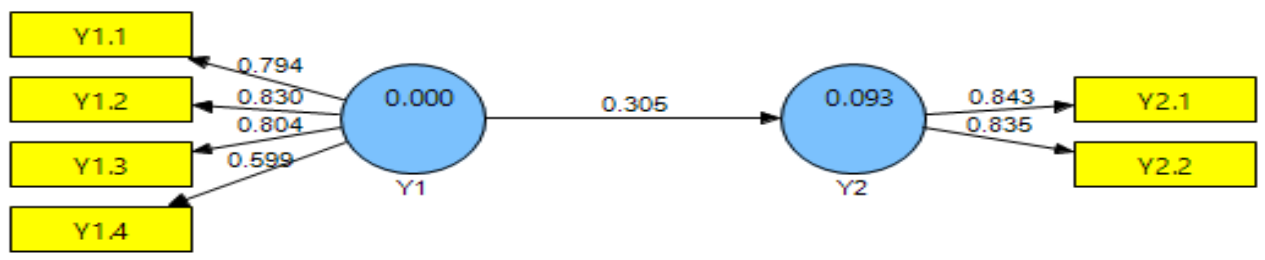

Figure 3 - Path diagram

Some studies that support the findings of the study include Efendi (2004) found that the level of innovation adoption of Lowland Vegetable Crops (LVC) technology is influenced by one element of group dynamics, namely group effectiveness. Svenek (2001), Sutarno (2015), and Wicaksono, A.S., and Subekti, S. (2017) stated the same thing that the effectiveness of farmer groups consisting of cognitive, affective and psychomotor indicators jointly influenced the level of technology adoption. Prajawahyudo et al., (2010) found the fact that farmer group effectiveness had a positive effect on the level of innovation adoption. Where effectiveness is measured based on indicators of performance, satisfaction and commitment. Farmer satisfaction affects the sustainability of the extension program and will have an impact on adoption improvement (Elias et al. 2015). Nuryanti and Swastika (2011) the role of farmer groups is not only as a medium for disseminating subsidies from the government, but more importantly as agents of application (adoption) of new technologies. Factors that influence the adoption of technological innovations in the Upsus Pajale (padi, jagung and kedelai / rice, corn and soybeans) activities include the role of information media and the role of farmer group communication (Adawiyah et al., 2017). The level of innovation adoption of Integrated Crop Management / of lowland rice one of them is the availability of information on Integrated Crop Management technology (Ismilaili et al., 2015). Farmer satisfaction affects the sustainability of the extension program and will have an impact on the adoption improvement (Elias et al. 2015). The impact of the adoption of agricultural technology innovations increases significantly over time (Ogundari and Bolarinwa, 2018). Implementation of integrated crop management practices such as balanced fertilizer applications can increase yields and income by around $30 \%$ compared to conventional farming systems in Karnataka, India (Wani et al., (2017). The communication effectiveness in receiving messages results in high knowledge of farmer about modern farming methods, which has the effect of increasing farmers' adoption (Rintjap, 2015). The role of farmer groups is not only as a medium for channeling government subsidies but also as an agent for implementing new technologies (Nuryanti and Swastika, 2011). While Djoni and Maulana (2009) get the fact that there is no relationship between group effectiveness with the adoption of technological innovation.

Table 13 - Results of the determination coefficient $\left(R^{2}\right)$

\begin{tabular}{cc}
\hline & R Square \\
\hline $\mathrm{Y} 2$ & 0.093 \\
\hline
\end{tabular}

Source: Research data processed (2018). 
Table 13 shows that the variable of the level of innovation adoption (Y2) is influenced by the variable of the effectiveness of the farmer group (Y1) with the value of the coefficient of determination ( $R$ square) equal to 0,093 . This shows that the variable of the effectiveness of the farmer group (Y1) has an effect of $9,30 \%$ on the level of innovation adoption (Y2), while the remaining $90,70 \%$ is influenced or determined by other factors not included in the model. The results of this study indicate that the effectiveness of farmer groups influences the adoption of innovation. This means that if the farmer group is not effective it will result in a less optimal level of the adoption of innovation so that it will have an impact on production improvement and farming productivity.

\section{CONCLUSION AND SUGGESTIONS}

The average value of the innovation adoption level variable is in the very appropriate as the recommended category. While the average value of the variable of the effectiveness of farmer groups is in the good category. The variable of effectiveness of farmer groups (Y1) has a significant and positive effect on the level of innovation adoption (Y2) in the Integrated Crop Management / model with 2 (Two) technological components, namely basic technological components and selected technological components through Integrated Crop Management-implementation Movement. The value of coefficient of determination $\left(R^{2}\right)$ shows that the effectiveness of farmer groups gives a positive contribution on the level of innovation adoption. The path coefficient shows that there is a positive effect, meaning that the higher the effectiveness of the farmer group (Y1) will lead to higher influence on the level of innovation adoption (Y2). From the analysis of research results and conclusions it can be suggested that the level of innovation adoption category can be maintained, while the effectiveness of farmer groups from good categories can be increased to very good categories, by taking into account the indicators that are still lacking. Given that the effectiveness of farmer groups contributes positively to the level of adoption of innovation, then the variables need to be considered and improved.

\section{APPENDIX}

Appendix 1 - Statistics description of the effectiveness of farmer groups $(X)$

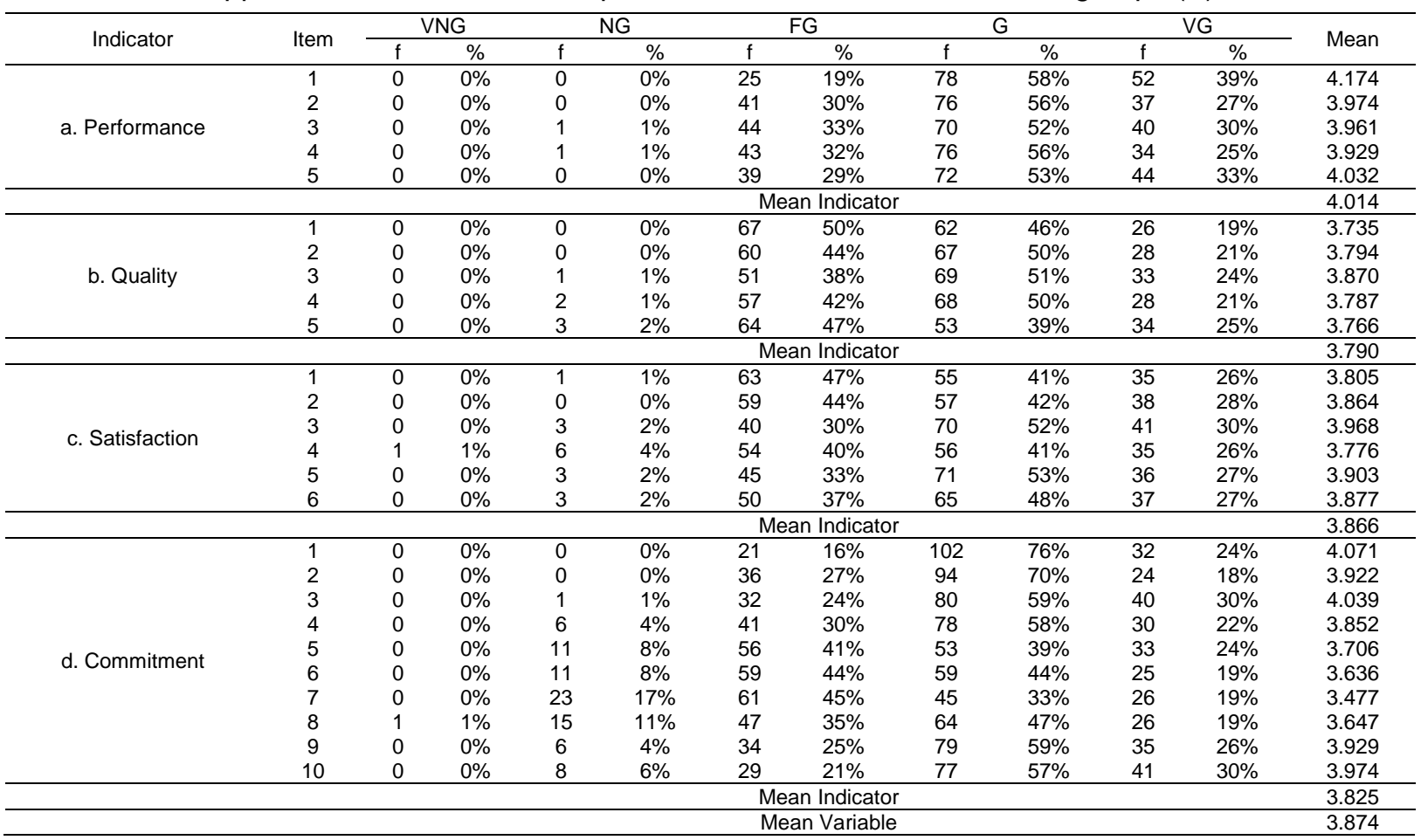

Source: Research data processed (2018). Description: VNG=Very Not Good, NG=Not Good, FG=Fairly Good, $\mathrm{G}=\mathrm{Good}$, and VG=Very Good. 
Appendix 2 - Statistics description of the level of adoption of innovation $(Y)$

\begin{tabular}{|c|c|c|c|c|c|c|c|c|c|c|c|c|}
\hline \multirow{2}{*}{ Indicator } & \multirow{2}{*}{ Item } & \multicolumn{2}{|c|}{ VNA } & \multicolumn{2}{|l|}{ NA } & \multicolumn{2}{|c|}{ FA } & \multirow{2}{*}{$\begin{array}{l}\text { A } \\
f\end{array}$} & \multicolumn{3}{|c|}{ VA } & \multirow{2}{*}{ Mean } \\
\hline & & $f$ & $\%$ & $f$ & $\%$ & $f$ & $\%$ & & $\%$ & f & $\%$ & \\
\hline \multirow{5}{*}{ a. Basic Technological Components } & 1 & 0 & $0 \%$ & 0 & $0 \%$ & 20 & $13 \%$ & 21 & $14 \%$ & 114 & $74 \%$ & 4.606 \\
\hline & 2 & 0 & $0 \%$ & 0 & $0 \%$ & 0 & $0 \%$ & 33 & $21 \%$ & 122 & $79 \%$ & 4.787 \\
\hline & 3 & 0 & $0 \%$ & 0 & $0 \%$ & 3 & $2 \%$ & 23 & $15 \%$ & 129 & $83 \%$ & 4.813 \\
\hline & 4 & 4 & $3 \%$ & 35 & $23 \%$ & 46 & $30 \%$ & 20 & $13 \%$ & 30 & $19 \%$ & 2.852 \\
\hline & 5 & 0 & $0 \%$ & 0 & $0 \%$ & 0 & $0 \%$ & 43 & $25 \%$ & 111 & $75 \%$ & 4.690 \\
\hline \multicolumn{8}{|c|}{ Mean Indicator } & & & & & 4.350 \\
\hline \multirow{7}{*}{ b. Selected Technological Components } & 1 & 0 & $0 \%$ & 0 & $0 \%$ & 0 & $0 \%$ & 29 & $19 \%$ & 126 & $81 \%$ & 4.813 \\
\hline & 2 & 0 & $0 \%$ & 0 & $0 \%$ & 7 & $5 \%$ & 46 & $30 \%$ & 102 & $66 \%$ & 4.523 \\
\hline & 3 & 0 & $0 \%$ & 0 & $0 \%$ & 5 & $3 \%$ & 45 & $29 \%$ & 105 & $68 \%$ & 4.645 \\
\hline & 4 & 0 & $0 \%$ & 12 & $8 \%$ & 8 & $5 \%$ & 60 & $39 \%$ & 75 & $48 \%$ & 4.277 \\
\hline & 5 & 0 & $0 \%$ & 0 & $0 \%$ & 4 & $3 \%$ & 16 & $10 \%$ & 131 & $85 \%$ & 4.716 \\
\hline & \multicolumn{5}{|c|}{ Mean Indicator } & & & & & & \multicolumn{2}{|c|}{4.599} \\
\hline & \multicolumn{5}{|c|}{ Mean Variable } & & & & & & \multicolumn{2}{|c|}{4.475} \\
\hline
\end{tabular}

Source: Research data processed (2018). Description: VNA= Very Not Appropriate, NA= Not Appropriate, $F A=$ Fairly Appropriate,$A=$ Appropriate, and $V A=$ Very Appropriate.

\section{REFERENCES}

1. Abdillah, W. and Jogiyanto, M.H. (2015). Partial Least Square (PLS): Alternatif Structural Equation Modelling (SEM) dalam Penelitian Bisnis. Yogyakarta: PenerbitANDI.

2. Adawiyah, C.R. (2017). Urgensi Komunikasi Dalam Kelompok Kecil Untuk Mempercepat Proses Adopsi Teknologi Pertanian. Jurnal Forum Penelitian Agro Ekonomi, Vol. 35(1).59-74.

3. Adawiyah, C.R., Sumardjo, and Mulyani, E.S. (2017). Faktor-Faktor yang Memengaruhi Peran Komunikasi Kelompok Tani dalam Adopsi Inovasi Teknologi Upaya Khusus (Padi, Jagung, and Kedelai) di Jawa Timur. Jurnal Agro Ekonomi, Vol. 35(2).151-170.

4. Arikunto, S. (2006). Prosedur Penelitian Suatu Pendekatan Praktik. Jakarta: Penerbit Rineka Cipta, Edisi Revisi VI.

5. Bachev, H. (2019). Sustainability of Farming Enterprises in Bulgaria. Cambridge Scholars Publishing.

6. Berg, H., \& Tam, N. T. (2018). Decreased use of pesticides for increased yields of rice and fish-options for sustainable food production in the Mekong Delta. Science of the Total Environment, 619, 319-327.

7. Bloomfield, G., Bucht, K., Martínez-Hernández, J. C., Ramírez-Soto, A. F., SheseñaHernández, I., Lucio-Palacio, C. R., \& Ruelas Inzunza, E. (2018). Capacity building to advance the United Nations sustainable development goals: An overview of tools and approaches related to sustainable land management. Journal of sustainable forestry, $37(2), 157-177$.

8. BPS. (2017). Kabupaten Kapuas Dalam Angka. Kabupaten Kapuas. Kuala Kapuas.

9. Burhansyah, R. (2016). Faktor-faktor yang mempengaruhi adopsi inovasi pertanian pada Gapoktan PUAP and Non PUAP di Kalimantan Barat (Studi kasus: Kab. Pontianak and Landak). Informatika Pertanian, 23(1), 65-74.

10. Cooper, D.R., and Schindler, P.S. (2006). Business Reserach Method. New York: McGraw-Hill Companies, Inc., $9^{\text {th }}$ Edition.

11. Dasgupta, S., Hossain, M. M., Huq, M., \& Wheeler, D. (2018). Climate change, salinization and high-yield Rice production in coastal Bangladesh. Agricultural and Resource Economics Review, 47(1), 66-89.

12. Dinas Pertanian. (2018). Sistem Informasi Manajemen Penyuluhan Pertanian. Kapuas: Kabupaten Kapuas.

13. Djoni, D., \& Maulana, F. A. (2009). Hubungan Antara Dinamika Kelompok Dengan Tanggap Adopsi Inovasi Budidaya Salak Pondoh. Jurnal Pembangunan Pedesaan, 9(1). 17-24

14. Effendi, M. (2004). Hubungan Dinamika Kelompok Tani Terhadap Penerapan Teknologi Tanaman Sayuran Dataran Rendah (TSDR). Jurnal EPP. 1(1).29-34.

15. Elias, A., Nohmi, M., Yasunobu, K, and Ishida, A. (2015). Elias, A., Nohmi, M., \& Yasunobu, K. (2016). Farmers' Satisfaction with Agricultural Extension Service and Its 
Influencing Factors: A Case Study in North West Ethiopia. Journal of Agricultural Science \& Technology, 18(1), 18.39-53.

16. Gabel, V. M., Home, R., Stolze, M., Birrer, S., Steinemann, B., \& Köpke, U. (2018). The influence of on-farm advice on beliefs and motivations for Swiss lowland farmers to implement ecological compensation areas on their farms. The Journal of Agricultural Education and Extension, 24(3), 233-248.

17. Ghozali, I. (2014). Structural Equation Modeling, Metode Alternatif Dengan Partial Least Square (PLS). Semarang: Badan Penerbit Universitas Diponegoro.

18. Giomi, T., Runhaar, P., \& Runhaar, H. (2018). Reducing agrochemical use for nature conservation by Italian olive farmers: An evaluation of public and private governance strategies. International journal of agricultural sustainability, 16(1), 94-105.

19. Hair, J.F., Hult, G.T.M, Ringle, C.M., and Sarstedt, M. (2017). A Primer on Partial Least Squares Structural Equation Modeling (PLS-SEM). Los Angeles: Sage Publication, Inc., Second Edition.

20. Hapsari, D. T., Suprijanto, M.S., and Susilawati. (2012). Faktor-Faktor Yang Memengaruhi Partisipasi Masyarakat Pada Kebun Bibit Rakyat (Studi Kasus Pengadaan Bibit Karet Untuk Petanbi di Kota Banjar baru. Jurnal EnviroScienteae, 8(2).55-61.

21. Hersey, P. and Blanchard, K. (2004). Management of Organizational Behavior.Englewood Cliffts. New Jersey: Prentice Hall.

22. Hidayat, N. K., Offermans, A., \& Glasbergen, P. (2018). Sustainable palm oil as a public responsibility? On the governance capacity of Indonesian standard for sustainable palm oil (ISPO). Agriculture and human values, 35(1), 223-242.

23. Hopkin, P. (2018). Fundamentals of risk management: understanding, evaluating and implementing effective risk management. Kogan Page Publishers.

24. Ismilaili, P, and Asngari, P.S., (2015). Tingkat Adopsi Inovasi Padi Sawah di Kecamatan Leuwiliang, Kabupaten Bogor. Jurnal Penyuluhan, 11(1).49-59.

25. Jamil, M. H., Musa, Y., Tenriawaru, A. N., \& Rahayu, N. E. (2018, May). The innovative characteristics and obstruction of technology adoption for management of integrated plants (PTT) of corn in Gowa Regency Indonesia. In IOP Conference Series: Earth and Environmental Science (Vol. 157, No. 1, p. 012054). IOP Publishing.

26. Jerop, R., Dannenberg, P., George Owuor, G., \& Mshenga, P. (2018). Factors affecting the adoption of agricultural innovations on underutilized cereals: The case of finger millet among smallholder farmers in Kenya. African Journal of Agricultural Research, 13(36), 1888-1900.

27. Kaputra, I. (2013). Alih Fungsi Lahan, Pembangunan Pertanian, and Kedaulatan Pangan, Jurnal Strukturasi, Vol. 1(1).25-39.

28. Kementerian Pertanian Rl. (2013). Peraturan Menteri Pertanian Nomor82/Permentan/OT.140/8/2013Tanggal 19 Agustus 2013 TentangPedoman Pembinaan KelembagaanTani and Gabungan Kelompok Tani. Jakarta: Kementerian Pertanian RI.

29. Kementerian Pertanian RI. (2015). Pemberdayaan Teknis Kelompok Tani di Lokasi Sentra Pangan Tahun 2016. Jakarta: Pusat Penyuluhan Pertanian Badan Penyuluhan and Pengembangan SDM Pertanian RI.

30. Kementerian Pertanian RI. (2016). Pedoman Umum Padi Sawah. Jakarta: Balai Penelitian and Pengembangan Pertanian.

31. Kidd, A. D., Lamers, J. P. A., Ficarelli, P. P., \& Hoffmann, V. (2000). Privatising agricultural extension: caveat emptor. Journal of Rural studies, 16(1), 95-102.

32. Kirschenbaum, A. (2019). Chaos organization and disaster management. Routledge.

33. Knickel, K., Redman, M., Darnhofer, I., Ashkenazy, A., Chebach, T. C., Šūmane, S., ... \& Strauss, A. (2018). Between aspirations and reality: Making farming, food systems and rural areas more resilient, sustainable and equitable. Journal of Rural Studies, 59, 197210.

34. Nuryanti, S. and Swastika, D.K.S. (2011). Peran Kelompok Tani Dalam Penerapan Teknologi Pertanian (Roles of Farmers' Groups in Agricultural Technology Adoption). Jurnal Forum Penelitian Agro Ekonomi. 29(2).115-128. 
35. Nyang'au, I., Kelboro, G., Hornidge, A. K., Midega, C., \& Borgemeister, C. (2018). Transdisciplinary Research: Collaborative Leadership and Empowerment Towards Sustainability of Push-Pull Technology. Sustainability, 10(7), 2378.

36. Ogundari, K. and Bolarinwa, O.D. (2018). Impact of agricultural innovation adoption: a meta-analysis. Australian Journal of Agricultural and Resource Economics, 59.1-20.

37. Peshin, R., Bano, F., \& Kumar, R. (2019). Diffusion and Adoption: Factors Impacting Adoption of Sustainable Agricultural Practices. In Natural Resource Management: Ecological Perspectives (pp. 235-253). Springer, Cham.

38. Prajawahyudo, T., Hariadi, S.S., and Widjaksono, R. (2010).Keefektifan Kelompok Tani Transmigran and Lokal Pada Usahatani Padi Sawah di Kabupaten Kapuas. Journal of Socio-Economics Agricultural (J-SEA). Jurusan Sosial Ekonomi Pertanian, PS. Agribisnis. Fakultas Pertanian Universitas Palangka Raya. 5 (1).51-60.

39. Putri, H. R.,(2016). Pengaruh Pendidikan, Pengalaman Kerja, and Jenis Kelamin Terhadap Produktivitas Kerja Karyawan Bagian Produksi CV. Karunia Abadi Wonosobo. Jurnal Pendidikan and Ekonomi, 5(4).292-300.

40. Rintjap, A.K. (2015). Efektivitas komunikasi dalam penerimaan informasi pada kelompok peternak sapi potong di Kecamatan Remboken, Kabupaten Minahasa, Sulawesi Utara (Effective communication of information recipient in cattle farmer groups in Remboken, Minahasa District, North Sulawesi). Prosiding Seminar Nasional Masyarakat Biodiversitas Indonesia. 1(7).(1711-1714. Oktober 2015 ISSN: 2407-8050. DOI: 10.13057/psnmbi/m010733.

41. Rosenzweig, M. R. (1977). Farm-family schooling decisions: Determinants of the quantity and quality of education in agricultural populations. Journal of Human Resources, 71-91.

42. Rusono. (2014). Permasalahan and Strategi Pembangunan Komoditas Beras di Indonesia (http://kab.faperta.ugm.ac.id).

43. Sherman, S., Hadar, I., \& Luria, G. (2018). Leveraging organizational climate theory for understanding industry-academia collaboration. Information and Software Technology, 98, 148-160.

44. Silva, A. G., Canavari, M., \& Sidali, K. L. (2018). A Technology Acceptance Model of common bean growers' intention to adopt Integrated Production in the Brazilian Central Region. Die Bodenkultur: Journal of Land Management, Food and Environment, 68(3), 131-143.

45. Stevenson, J., Vanlauwe, B., Macours, K., Johnson, N., Krishnan, L., Place, F., ... \& Vlek, P. (2019). Farmer adoption of plot-and farm-level natural resource management practices: Between rhetoric and reality. Global Food Security, 20, 101-104.

46. Sutarno, S. (2015). Kajian Efektivitas and Dinamika Kelompok Terhadap Adopsi Budidaya Sayuran Organik di Desa Pulutan Wetan Wonogiri. Jurnal AGRINECA. 15 (1) ejournal.utp.ac.id.

47. Svenek, T.M. (2001). Hubungan Dinamika Dengan Efektivitas Kelompok and Pengaruhnya Terhadap Adopsi Inovasi Ayam Buras di Kabupaten Bantul.Unpublished Tesis S2. Yogyakarta: Universitas Gadjah Mada.

48. Swanson, B. (2005). Improving agricultural extension. Daya Books.

49. Umstot, D.D. (1988). Understanding Organizational Behavior. USA: West Publishing Company, $2^{\text {nd }}$ Edition.

50. Van Tran, D. (1998). World rice production: main issues and technical possibilities. Cahiers Options Méditerranéennes, 24(2).

51. Wahed, M. (2015). Pengaruh Luas Lahan, Produksi, Ketahanan Pangan and Harga Gabah Terhadap Kesejahteraan Petani Padi di Kabupaten Pasuruan. JESP,7 (1).68-74.

52. Wani, S.P., Anantha, K.H. and Garg, K.K. (2017). Soil Properties, Crop Yield, and Economics Under Integrated Crop Management Practices in Karnataka, Southern India. India: Article in World Development, 93.43-61.

53. Wicaksono, A.S., and Subekti, S. (2017). Hubungan Dinamika Kelompok Tani dengan Adopsi Good Tobacco Practices (GTP) Tembakau Voor-Oogst Kasturi. Jurnal JSEP, 10(2).8-17. 
54. Wijaya, A., Glasbergen, P., Leroy, P., \& Darmastuti, A. (2018). Governance challenges of cocoa partnership projects in Indonesia: seeking synergy in multi-stakeholder arrangements for sustainable agriculture. Environment, development and sustainability, 20(1), 129-153.

55. Wiyono, G. (2011). Merancang Penelitian Bisnis Dengan Alat Analisis SPSS 17.0 and SmartPLS 2.0. Yogyakarta: Unit Penerbit and Percetakan STIM YKPN.

56. Wuepper, D., Sauer, J., \& Kleemann, L. (2018). Sustainable intensification amongst Ghana's pineapple farmers: the complexity of an innovation determines the effectiveness of its training. Environment and Development Economics, 23(1), 98-119.

57. Xie, Z., \& Zhong, F. (2006). Mobility of Rural Workers, Human Capital, and Social Resources: Results and Analysis on Household Survey in Jiangsu Province [J]. Issues in Agricultural Economy, 8.

58. Xuan, V. T. (2018). Rice production, agricultural research, and the environment. In Vietnam's rural transformation (pp. 185-200). Routledge.

59. Yunasaf, U. (2007). Kepemimpinan Ketua Kelompok and Hubungannya Dengan Keefektifan Kelompok (Kasus Kelompok Tani Ternak Sapi Perah di Wilayah Kerja Koperasi Serba Usaha Tandangsari Sumedang). Jurnal IImu Ternak, 7(2).179-185.

60. Zarić, V., Petković, D., \& Radošević, M. (2018). Consumer perception towards traditional Serbian agricultural and food products. Economics of Agriculture, 57(Special nu), 57-66. 